\title{
The Interactive Effect of High Doses of Chromium(III) and Different Iron(III) Levels on the Carbohydrate Status, Lipid Profile, and Selected Biochemical Parameters in Female Wistar Rats
}

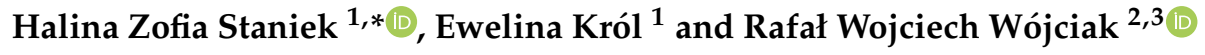 \\ 1 Department of Human Nutrition and Dietetics, Poznan University of Life Sciences, 60-624 Poznan, Poland; \\ ewelina.krol@up.poznan.pl \\ 2 Department of Clinical Psychology, Poznan University of Medical Sciences, 60-812 Poznan, Poland; \\ rafwoj@ump.edu.pl \\ 3 Department of Dietetics, Faculty of Physical Culture in Gorzow Wielkopolski, Poznan University of Physical \\ Education, 61-871 Poznan, Poland \\ * Correspondence: halina.staniek@up.poznan.pl; Tel.: +48-(61)-8487334
}

Received: 2 September 2020; Accepted: 6 October 2020; Published: 8 October 2020

check for updates

\begin{abstract}
The aim of the study was to evaluate the main and interactive effects of chromium(III) propionate complex $(\mathrm{Cr} 3)$ supplementation and different iron supply on the carbohydrate metabolism, lipid profile and other selected biochemical parameters of rats. The experiment was carried out in a two-factor design, in which rats were fed a diet with different proportions of $\mathrm{Fe}(\mathrm{III})$ and $\mathrm{Cr}$ (III) for six weeks. Fifty-four healthy female Wistar rats were divided into nine experimental groups with different $\mathrm{Fe}(\mathrm{III})$ levels, i.e. adequate—control group $(45 \mathrm{mg} / \mathrm{kg})-100 \%$ recommended daily dietary dose of Fe for rodents, deficient ( $5 \mathrm{mg} / \mathrm{kg}$ ) and oversupply $(180 \mathrm{mg} / \mathrm{kg}-400 \%)$. At the same time they were supplemented with $\mathrm{Cr}$ (III) of doses 1 (adequate), 50 and $500 \mathrm{mg} / \mathrm{kg}$ of diet. The activity and concentrations of most biochemical parameters were measured with standard enzymatic, kinetic, and colorimetric methods. HOMA-IR and QUICKI indexes were calculated according to appropriate formulas. It was found that there was an interactive effect of high $\mathrm{Cr}$ (III) doses and different $\mathrm{Fe}(\mathrm{III})$ levels in the diet on the carbohydrate metabolism and insulin resistance indexes. The presented results suggested that iron deficient diet fed animals led to insulin resistance; however, an effect is attenuated by $\mathrm{Cr}$ (III) supplementation at high doses. There were no significant changes in the rats' lipid profile (except for the high density lipoprotein cholesterol (HDL-C) level) and most of the other biochemical parameters, such as the leptin, aspartate aminotransferase (AST), alanine transaminase (ALT), total protein (TP), creatinine (Crea) and the urea (BUN) concentrations. The study proved that the $\mathrm{Cr}$ (III) supplementation, independently and in combination with diversified Fe(III) content in the diet, affected the carbohydrate metabolism and insulin resistance indexes but did not affect lipid profile and most of the other biochemical parameters in healthy rats. The findings proved the role of Fe and $\mathrm{Cr}(\mathrm{III})$ and their interactions on disturbances carbohydrates metabolism.
\end{abstract}

Keywords: Fe deficiency; Fe excess; chromium(III); interactions; carbohydrates metabolism; biochemical parameters; rats

\section{Introduction}

An inadequate supply of nutrients in the diet and their abnormal levels in the body can lead to many metabolic disorders. Minerals are significant to normal body function because they participate in numerous metabolic processes. However, the role of some elements, especially: $\mathrm{Fe}, \mathrm{Cr}(\mathrm{III}), \mathrm{Zn}, \mathrm{Cu}$, 
and $\mathrm{Mg}$ in the pathogenesis of insulin resistance, diabetes, anemia, and Fe overload has not been fully elucidated and their mechanisms are not fully clear. Recent experimental and clinical trials have shown that there is a relationship between the consumption of minerals, their levels, and distribution in the body and the occurrence of metabolic disorders [1-4].

Iron deficiency is one of the most common nutritional deficiencies [5]. Statistics show that it affects about 1.5-1.8 billion people worldwide [6-8]. According to the $\mathrm{WHO}, 5 \%$ of the world population, $20 \%$ of menstruating women, and $30-40 \%$ of children in developed countries suffer from iron deficiency [9]. This element in the appropriate amount is necessary for the proper function of the organism. It is an ingredient of hemoglobin, myoglobin, and various enzymes involved in the transport and storage of oxygen and electron transport. Fe deficiency contributes to the reduction of oxygen transport capacity, energy production, and cell proliferation [10]. It is a frequent cause of anemia [11]. It is estimated that over $30 \%$ of the global population has anemia, mainly due to Fe deficiency $[12,13]$. It is mainly caused by insufficient supply of iron with diet, impaired absorption of this element, excessive blood loss in menstrual cycles, diseases such as diabetes mellitus (DM), inflammatory bowel disease (IBD), and increased physiological requirements for iron, e.g., in pregnancy and lactation [14].

On the other hand, researchers also pay more and more attention to the consequences of excessive iron accumulation in the body, which may be harmful [15]. The accumulation of macro- and microelements in the body is mainly caused by environmental pollution, improper diet, or metabolic disorders [16]. Iron is both naturally found and added purposely to various foods. It is also available as dietary supplements. Public health interventions, such as food fortification with iron compounds, have been undertaken to reduce the incidence of Fe deficiency anemia and to improve health. These activities as well as uncontrolled and unjustified dietary supplementation with Fe compounds arouse a lot of controversy because some groups of people are at higher risk of Fe overload due to additional exposure to Fe in the diet $[15,17]$. For example, predisposition to increased absorption and accumulation of iron from the diet has people with hereditary hemochromatosis [18].

Another global problem is diabetes and the costs of its treatment. It is estimated that the number of people with diabetes will have increased to 693 million by 2045 [19]. Some studies suggest a specific role of selected trace elements in the pathogenesis and progression of this disease [1,20]. Therefore, the maintenance of trace element homeostasis is essential for the regulation of numerous metabolic functions in the organism. Imbalance of trace elements may disturb proper carbohydrate and lipid metabolism or cause oxidative stress, which may contribute to insulin resistance and the development of diabetes complications [1,21,22].

It was stated that iron homeostasis is disturbed in diabetes [2,4,20,23-27]. There are many hypotheses concerning the mechanism of its participation in the development of diabetes. Most of the evidence supports the hypothesis that disturbed Fe homeostasis causes the overproduction of free radicals and induces oxidative stress [28-30].

On the other hand, trivalent chromium compounds are very popular supplements among diabetics. Since 2014, the "essentiality" of chromium has been questioned by EFSA and they no longer consider it necessary for humans and animals due to the ubiquitous nature of this element and its low dietary requirements [31,32]. Despite this, the beneficial effects of pharmacological doses of chromium(III) have been demonstrated in people with glucose metabolic disorders such as diabetes. According to McIver et al. [33], the risk of type 2 diabetes mellitus (T2DM) was lower in people consuming Cr(III) supplements. Therefore, new $\mathrm{Cr}$ (III) compounds, especially organic ones, are being sought. Their forms should exhibit a significant degree of absorption, safety, and efficacy, especially to improve glucose and lipid metabolism in patients with diabetes. One of these compounds is the tri-nuclear $\mathrm{Cr}$ (III) complex with propionic acid, aka Cr3, or CrProp. Our earlier study, as well as other authors' studies, showed that in comparison with other $\mathrm{Cr}$ (III) compounds, Cr3 was characterized by a significant degree of absorption (40-60\%) and it was relatively safe (LD50 $>2000 \mathrm{mg} / \mathrm{kg}$ body weight (b.w.)) [34-37].

It is thought that both Fe and $\mathrm{Cr}$ (III) may play an important role in the pathogenesis of diabetes, but their mechanisms of action are not fully understood. In vitro conditions, it was found that Fe(III) 
and $\mathrm{Cr}(\mathrm{III})$ are transported by the same protein-transferrin (Tf) - and can compete for binding to it. Thus, they may mutually inhibit absorption and transport to tissues [38]. These interactions may affect Fe and $\mathrm{Cr}$ homeostasis in the body and thus interfere with some metabolic functions. Therefore, it seems reasonable to include the interaction between these elements and their role in the etiology of the development of type 2 diabetes and cardiovascular disease. The effects of $\mathrm{Cr}$ (III) supplementation with an insufficient or excessive supply of Fe in vivo conditions are not known yet. In our opinion, the interaction between these elements and their effect on the development of carbohydrate and lipid metabolism disorders is also an important issue.

Therefore, the research hypothesized was that there is interaction between $\mathrm{Fe}(\mathrm{III})$ and $\mathrm{Cr}$ (III). The direction of this action depends on their mutual proportions in the diet and organism and determines the body's response, which is manifested by disturbed carbohydrate and lipid metabolism.

\section{Material and Methods}

\subsection{Test Chemicals}

Chromium(III) propionate (Cr3 or CrProp) in the form of nitrate salt $\left.\left[\mathrm{Cr}_{3} \mathrm{O}\left(\mathrm{O}_{2} \mathrm{CCH}_{2} \mathrm{CH}_{3}\right)_{6}\left(\mathrm{H}_{2} \mathrm{O}\right)_{3}\right] \mathrm{NO}_{3}\right]$ was used as a source of $\mathrm{Cr}(\mathrm{III})$ in the diet. The complex was synthesized by the modified methodology described by Earnshaw et al. [39]. The Cr3 complex contained $21.5 \%$ of $\mathrm{Cr}$, which was measured with a AAS-3 spectrometer with background correction (Carl-Zeiss, Jena, Germany).

As a source of $\mathrm{Fe}(\mathrm{III})$ in the diet was used iron(III) citrate-the compound recommended for rodents (reagent grade, $16.6 \%$ Fe) [40]—which was purchased from Sigma-Aldrich (St. Louis, MO, USA).

\subsection{Animals and Diets}

The study was conducted in a two-factor design, with three different doses of Cr(III) [1 (control), 50 , and $500 \mathrm{mg} / \mathrm{kg}$ ] and three different levels of Fe(III) in the diet [deficient (D) - $5 \mathrm{mg} / \mathrm{kg}$, control (C) $-45 \mathrm{mg} / \mathrm{kg}$ and excess $(\mathrm{E})-180 \mathrm{mg} / \mathrm{kg}]$. The model study was approved by the Local Animals Ethics Committee (approval number: 60/2013). The fifty-four 6-week-old female Wistar rats (Rattus norvegicus) were obtained from the Department of Toxicology, Poznan University of Medical Sciences, Poland.

The rats had been acclimated for 5 days before the study began. Then, the animals were divided into 9 groups, each with an initial mean body weight (b.w.) of $130.5 \mathrm{~g}$. During the experiment the rats were housed in single cages, transparent under optimal and controlled living conditions (temperature 19-22 ${ }^{\circ} \mathrm{C}$, air humidity 55-60\%, $12 \mathrm{~h}$ light/12 h dark cycle). Access to diets and water were ad libitum throughout the whole study. For 6 weeks the rats were fed semi-purified AIN-93M diets composed according to the recommendations of the American Institute of Nutrition [40] and modified for the content of $\mathrm{Fe}(\mathrm{III})$ and $\mathrm{Cr}$ (III) in the diet. The detailed chemical composition of the experimental diets was checked and shown in Table 1. 
Table 1. The chemical composition of diets (mean \pm SD).

\begin{tabular}{|c|c|c|c|c|c|c|c|c|c|c|}
\hline \multirow{2}{*}{ Ingredients } & \multirow{2}{*}{ Unit } & \multicolumn{9}{|c|}{ Content of Ingredients in Diets } \\
\hline & & $\mathrm{C} 1$ & C50 & C500 & D1 & D50 & D500 & E1 & E50 & E500 \\
\hline Energy & MJ 100/g & $1.82 \pm 0.00$ & $1.83 \pm 0.03$ & $1.89 \pm 0.06$ & $1.92 \pm 0.05$ & $1.80 \pm 0.04$ & $1.87 \pm 0.03$ & $1.88 \pm 0.04$ & $1.82 \pm 0.03$ & $1.81 \pm 0.02$ \\
\hline Fat & $\%$ & $7.46 \pm 0.05$ & $7.22 \pm 0.08$ & $7.26 \pm 0.31$ & $7.36 \pm 0.24$ & $6.62 \pm 0.29$ & $7.19 \pm 0.10$ & $7.31 \pm 0.10$ & $7.11 \pm 0.06$ & $6.83 \pm 0.05$ \\
\hline Protein & $\%$ & $17.12 \pm 0.10$ & $17.17 \pm 0.14$ & $17.27 \pm 0.24$ & $17.64 \pm 0.35$ & $17.90 \pm 0.13$ & $17.22 \pm 0.16$ & $17.42 \pm 0.30$ & $17.01 \pm 0.12$ & $17.72 \pm 0.39$ \\
\hline Carbohydrates & $\%$ & 63.46 & 63.67 & 63.45 & 63.55 & 64.12 & 63.78 & 64.05 & 63.11 & 64.77 \\
\hline Dry Mass & $\%$ & $90.47 \pm 0.05$ & $90.54 \pm 0.22$ & $90.26 \pm 0.08$ & $90.14 \pm 0.26$ & $89.40 \pm 0.03$ & $89.70 \pm 0.14$ & $89.99 \pm 0.36$ & $89.67 \pm 0.54$ & $89.90 \pm 0.23$ \\
\hline Ash & $\%$ & $2.47 \pm 0.04$ & $2.48 \pm 0.11$ & $2.32 \pm 0.50$ & $2.45 \pm 0.08$ & $2.77 \pm 0.05$ & $2.63 \pm 0.12$ & $2.36 \pm 0.21$ & $2.67 \pm 0.08$ & $2.58 \pm 0.08$ \\
\hline $\mathrm{Ca}$ & $\mathrm{g} / \mathrm{kg}$ & $4.96 \pm 0.13$ & $5.16 \pm 0.13$ & $5.02 \pm 0.11$ & $5.00 \pm 0.19$ & $5.10 \pm 0.11$ & $5.02 \pm 0.37$ & $5.17 \pm 0.02$ & $5.09 \pm 0.11$ & $4.94 \pm 0.17$ \\
\hline $\mathrm{Mg}$ & $\mathrm{mg} / \mathrm{kg}$ & $441.42 \pm 8.99$ & $473.12 \pm 1.44$ & $511.73 \pm 17.55$ & $478.69 \pm 15.46$ & $473.73 \pm 56.11$ & $529.95 \pm 13.13$ & $503.86 \pm 23.80$ & $501.62 \pm 19.90$ & $529.98 \pm 15.50$ \\
\hline $\mathrm{Fe}$ & $\mathrm{mg} / \mathrm{kg}$ & $58.05 \pm 0.70$ & $57.09 \pm 2.83$ & $59.13 \pm 1.98$ & $3.43 \pm 0.38$ & $3.30 \pm 1.08$ & $3.03 \pm 0.59$ & $218.12 \pm 7.53$ & $207.55 \pm 21.49$ & $229.78 \pm 13.04$ \\
\hline $\mathrm{Cr}$ & $\mathrm{mg} / \mathrm{kg}$ & $1.24 \pm 0.23$ & $50.04 \pm 6.48$ & $425.14 \pm 10.28$ & $1.69 \pm 0.12$ & $48.89 \pm 2.00$ & $459.14 \pm 24.42$ & $1.95 \pm 0.61$ & $49.42 \pm 5.40$ & $431.59 \pm 14.82$ \\
\hline $\mathrm{Zn}$ & $\mathrm{mg} / \mathrm{kg}$ & $52.51 \pm 1.60$ & $50.71 \pm 1.90$ & $52.41 \pm 2.02$ & $49.26 \pm 9.70$ & $45.90 \pm 7.51$ & $44.41 \pm 5.66$ & $44.80 \pm 4.21$ & $40.86 \pm 0.49$ & $43.13 \pm 3.00$ \\
\hline $\mathrm{Cu}$ & $\mathrm{mg} / \mathrm{kg}$ & $5.45 \pm 0.94$ & $4.43 \pm 0.15$ & $5.93 \pm 0.79$ & $5.11 \pm 0.88$ & $5.53 \pm 0.90$ & $5.51 \pm 0.60$ & $5.82 \pm 0.71$ & $6.28 \pm 0.20$ & $6.62 \pm 1.02$ \\
\hline
\end{tabular}


Fifty-four healthy female Wistar rats were divided into 9 experimental groups $(n=6)$ with different Fe(III) and Cr(III) levels, as was shown in Table 2. The diet intake was recorded daily. Body weight gains were monitored weekly.

Table 2. Model of the experiment.

\begin{tabular}{|c|c|c|c|}
\hline Factor & Groups & $\begin{array}{c}N \\
(54)\end{array}$ & Level of Factor \\
\hline \multirow{3}{*}{$\begin{array}{c}\text { Factor A } \\
\text { Fe Level in Diet }\end{array}$} & $\mathbf{D}$ & 18 & $\begin{array}{l}\text { A1-10\% recommended Fe level in the diet for rodents } \\
\qquad(5 \mathrm{mg} / \mathrm{kg})(\mathrm{Fe}-\text { deficiency) }\end{array}$ \\
\hline & $\mathrm{C}$ & 18 & $\begin{array}{l}\text { A2-recommended Fe level in the diet for rodents } \\
\qquad(45 \mathrm{mg} / \mathrm{kg})(\mathrm{Fe}-\text { control })\end{array}$ \\
\hline & $\mathbf{H}$ & 18 & $\begin{array}{l}\text { A3-400\% recommended Fe level in the diet for rodents } \\
\qquad(180 \mathrm{mg} / \mathrm{kg})(\mathrm{Fe}-\text { oversupply) }\end{array}$ \\
\hline \multirow{3}{*}{$\begin{array}{c}\text { Factor B } \\
\text { Cr(III) Level in Diet }\end{array}$} & 1 & 18 & $\begin{array}{l}\text { B1-recommended } \mathrm{Cr}(\mathrm{III}) \text { level in the diet for rodents } \\
\qquad(1 \mathrm{mg} / \mathrm{kg})(\mathrm{Cr} \text {-control dose })\end{array}$ \\
\hline & 50 & 18 & $\begin{array}{l}\text { B2-I supplemental dose of } \mathrm{Cr}(\mathrm{III}) \\
(50 \mathrm{mg} / \mathrm{kg})(\mathrm{Cr}-\text { medium dose })\end{array}$ \\
\hline & 500 & 18 & $\begin{array}{l}\text { B3-II supplemental dose of } \mathrm{Cr}(\mathrm{III}) \\
(500 \mathrm{mg} / \mathrm{kg})(\mathrm{Cr} \text {-high dose })\end{array}$ \\
\hline Combinations Factors & & $\begin{array}{c}N \\
(54)\end{array}$ & \\
\hline A1B1 & D1 & 6 & Fe 5 mg/kg, Cr 1 mg/kg \\
\hline A1B2 & D50 & 6 & Fe $5 \mathrm{mg} / \mathrm{kg}$, Cr $50 \mathrm{mg} / \mathrm{kg}$ \\
\hline A1B3 & D 500 & 6 & $\mathrm{Fe} 5 \mathrm{mg} / \mathrm{kg}$, Cr $500 \mathrm{mg} / \mathrm{kg}$ \\
\hline A2B1 & C1 (control) & 6 & $\mathrm{Fe} 45 \mathrm{mg} / \mathrm{kg}$, Cr $1 \mathrm{mg} / \mathrm{kg}$ \\
\hline A2B2 & C50 & 6 & $\mathrm{Fe} 45 \mathrm{mg} / \mathrm{kg}$, Cr $50 \mathrm{mg} / \mathrm{kg}$ \\
\hline A2B3 & C500 & 6 & $\mathrm{Fe} 45 \mathrm{mg} / \mathrm{kg}$, Cr $500 \mathrm{mg} / \mathrm{kg}$ \\
\hline A3B1 & H1 & 6 & $\mathrm{Fe} 180$ mg/kg, Cr 1 mg/kg \\
\hline A3B2 & H50 & 6 & $\mathrm{Fe} 180 \mathrm{mg} / \mathrm{kg}$, Cr $50 \mathrm{mg} / \mathrm{kg}$ \\
\hline A3B3 & H500 & 6 & $\mathrm{Fe} 180 \mathrm{mg} / \mathrm{kg}$, Cr 500 mg/kg \\
\hline
\end{tabular}

\subsection{Data Collection}

After the experiment the animals were euthanized by asphyxiation with $\mathrm{CO}_{2}$. Blood was drawn from the rats' hearts and collected into tubes containing EDTA. Next, it was centrifuged $(3500 \times g$ for $10 \mathrm{~min}, 4^{\circ} \mathrm{C}$ ) for further analyses. Most of the tested parameters in blood plasma were measured immediately after sampling, except for insulin, leptin, and ghrelin, which were measured later from samples frozen at $-80^{\circ} \mathrm{C}$.

\subsection{Laboratory Analyses}

Chemical composition of diets was determined based on the standard assays: the protein content - the Kjeldahl method, the fat content—-the Soxhlet method. The ash content was determined by burning diet samples in muffle furnace at temperature $550{ }^{\circ} \mathrm{C}$. The diet samples for mineral analyses were digested with concentrated 65\% spectra pure nitric acid (Merck) in a Microwave Digestion System MARS-5 (CEM, Matthews, NC, USA). The concentration of tested elements in mineralised samples was determined with the flame atomic absorption spectrometry (F-AAS) (AAS-3, with background correction, Carl-Zeiss, Jena, Germany).

The following standard methods were used to measure blood plasma indices with Cobas analysers (Cobas Integra 400 and 800 analysers, Roche Diagnostics (Hitachi, Tokyo, Japan). The plasma glucose concentration was measured with the hexokinase method [41]. The triglycerides (TG), total cholesterol (T-Chol), high density lipoprotein cholesterol (HDL-C) and low density lipoprotein cholesterol (LDL-C) concentrations were measured with the colorimetric methods [42-44]. The activity 
of alanine transaminase (ALT), aspartate aminotransferase (AST) and alkaline phosphatase (ALP), and the urea (BUN) concentration were measured with the kinetic methods [44-46]. The total protein concentration (TP) was measured with the colorimetric method, using $\mathrm{Cu}^{2+}$ ions [44]. The creatinine (Crea) concentration was measured with the kinetic colorimetric method [46]. The serum insulin, ghrelin, and leptin concentrations were measured with ELISA kits (EZRMI-13K and EZRL-83K, Millipore Corporation, Burlington, MA, USA; EZRGRT-91K, Linco Research, St Charles, MO, USA). The homeostatic model assessment for insulin resistance (HOMA-IR) and the quantitative insulin sensitivity check index (QUICKI) were calculated in accordance with the standard formulas from fasting plasma glucose and insulin [47-49].

\subsection{Statistical Analysis}

The data obtained in the study were processed with the Statistica software version 13.3 for Windows (StatSoft, Cracow, Poland) and shown as arithmetic mean \pm standard deviation (SD). The results were analysed with two-way analysis of variance (two-way ANOVA/MANOA, factors of $\mathrm{Fe}(\mathrm{III})$ and $\mathrm{Cr}$ (III) dietary content, test F). If the two-way ANOVA indicated a significant Fe(III) content effect, $\mathrm{Cr}$ (III) level effect, or Fe $\times \mathrm{Cr}$ interaction, a subsequent one-way ANOVA and post hoc comparison were applied using Tukey-test with significance set at $p<0.05$.

\section{Results}

The effects of different levels Fe(III) and Cr(III) on the rats' carbohydrate metabolism and insulin resistance indexes are shown in Table 3. Both the iron deficiency and excess reduced the glucose concentration $(p<0.05)$ by $16.5 \%$ and $19.1 \%$, respectively, as compared with the control level. While the high doses of $\mathrm{Cr}$ (III) did not affect the glucose concentration in the experimental animals. There was no interactive effect of the experimental factors on this parameter. The diversified Fe(III) supply and $\mathrm{Cr}$ (III) supplementation in the diet affected both independently and in a combination the insulin concentration and insulin resistance indexes, such as HOMA-IR (Homeostatic Model Assessment of Insulin Resistance) and Quciki (Quantitative Insulin Sensitivity Check Index) (Table 3). 
Table 3. The effects of the Fe(III) and Cr(III) levels in the diet on the glucose and insulin concentrations and parameters of insulin resistance in rats.

\begin{tabular}{|c|c|c|c|c|c|c|c|c|c|c|c|c|}
\hline \multirow{3}{*}{ Factors } & \multirow{3}{*}{$\begin{array}{c}\text { Factor A } \\
\text { Level } \\
(\mathrm{mg} / \mathrm{kg})\end{array}$} & \multirow{3}{*}{$\begin{array}{l}\text { Factor B } \\
\text { Level } \\
(\mathrm{mg} / \mathrm{kg})\end{array}$} & \multirow{3}{*}{ Group } & \multirow{3}{*}{$N$} & \multicolumn{8}{|c|}{ Parameters } \\
\hline & & & & & $\begin{array}{l}\text { Glucose Concentration } \\
(\mathrm{mg} / \mathrm{dL})(\mathrm{mMol} / \mathrm{L})\end{array}$ & $p$ & Insulin $(\mathrm{ng} / \mathrm{mL})(\mathrm{mU} / \mathrm{L})$ & $p$ & HOMA-IR Index & $p$ & $\begin{array}{c}\text { Quicki } \\
\text { (Quantitative } \\
\text { Insulin Sensitivity } \\
\text { Check Index) }\end{array}$ & $p$ \\
\hline & & & & & \multicolumn{8}{|c|}{$\begin{array}{l}\text { Main Effects } \\
\text { (Mean } \pm \text { SD) }\end{array}$} \\
\hline Fe-deficiency & 5 & & $\mathrm{D}$ & 18 & $\begin{array}{l}147.78 \pm 29.75^{\mathrm{a}} \\
(8.203 \pm 1.652) \\
\end{array}$ & \multirow{3}{*}{$p<0.05$} & $\begin{array}{c}1.274 \pm 0.837^{\mathrm{b}} \\
(31.625 \pm 20.777) \\
\end{array}$ & & $11.72 \pm 8.97^{b}$ & \multirow{3}{*}{$p<0.001$} & $0.280 \pm 0.020^{\mathrm{a}}$ & \multirow{3}{*}{$p<0.001$} \\
\hline Fe-control & 45 & & C & 18 & $\begin{array}{c}176.89 \pm 44.80^{\mathrm{b}} \\
(9.819 \pm 2.487)\end{array}$ & & $\begin{array}{l}0.611 \pm 0.109 \text { a } \\
(15.167 \pm 2.715) \\
\end{array}$ & $p<0.001$ & $6.79 \pm 2.68^{a, b}$ & & $0.294 \pm 0.015^{\mathrm{b}}$ & \\
\hline Fe-oversupply & 180 & & $\mathrm{H}$ & 18 & $\begin{array}{c}143.11 \pm 37.933^{\mathrm{a}} \\
(7.944 \pm 2.105)\end{array}$ & & $\begin{array}{r}0.464 \pm 0.048^{\mathrm{a}} \\
(11.531 \pm 1.203) \\
\end{array}$ & & $4.06 \pm 1.10^{\mathrm{a}}$ & & $0.312 \pm 0.010^{c}$ & \\
\hline Cr-control dose & & 1 & 1 & 18 & $\begin{array}{l}156.28 \pm 45.21 \\
(8.675 \pm 2.510)\end{array}$ & \multirow{3}{*}{ NS } & $\begin{array}{c}1.108 \pm 0.942^{\mathrm{b}} \\
(27.512 \pm 23.379)\end{array}$ & & $10.53 \pm 9.69^{b}$ & \multirow{3}{*}{$p<0.001$} & $0.289 \pm 0.027^{a}$ & \multirow{3}{*}{$p<0.05$} \\
\hline $\begin{array}{l}\text { Cr-medium } \\
\text { dose }\end{array}$ & & 50 & 50 & 18 & $\begin{array}{l}154.11 \pm 39.49 \\
(8.554 \pm 2.192)\end{array}$ & & $\begin{array}{l}0.639 \pm 0.175 \text { a } \\
(15.853 \pm 4.357) \\
\end{array}$ & $p<0.001$ & $6.07 \pm 2.28^{\mathrm{a}, \mathrm{b}}$ & & $0.298 \pm 0.015^{a, b}$ & \\
\hline Cr-high dose & & 500 & 500 & 18 & $\begin{array}{l}157.39 \pm 37.83 \\
(8.736 \pm 2.100) \\
\end{array}$ & & $\begin{array}{r}0.602 \pm 0.150 \mathrm{a} \\
(14.957 \pm 3.716) \\
\end{array}$ & & $5.97 \pm 2.73^{a}$ & & $0.299 \pm 0.015^{b}$ & \\
\hline \multicolumn{5}{|c|}{ Factor Combinations } & \multicolumn{8}{|c|}{$\begin{array}{l}\text { Interaction Effects } \\
(\text { Mean } \pm \text { SD) }\end{array}$} \\
\hline \multirow{3}{*}{ Fe-deficiency } & 5 & 1 & D1 & 6 & $\begin{array}{l}148.00 \pm 37.27 \\
(8.215 \pm 2.069)\end{array}$ & \multirow{9}{*}{ NS } & $\begin{array}{c}2.292 \pm 0.688^{\mathrm{b}} \\
(56.903 \pm 17.074)\end{array}$ & \multirow{9}{*}{$p<0.001$} & $21.30 \pm 10.09 \mathrm{~b}$ & \multirow{9}{*}{$p<0.001$} & $0.257 \pm 0.013^{a}$ & \multirow{9}{*}{$p<0.001$} \\
\hline & 5 & 50 & D50 & 6 & $\begin{array}{l}156.00 \pm 32.65 \\
(8.659 \pm 1.812)\end{array}$ & & $\begin{array}{l}0.815 \pm 0.159^{\mathrm{a}} \\
(20.239 \pm 3.935)\end{array}$ & & $7.70 \pm 1.68^{a}$ & & $0.287 \pm 0.009^{b}$ & \\
\hline & 5 & 500 & D500 & 6 & $\begin{array}{l}139.33 \pm 19.69 \\
(7.734 \pm 1.093) \\
\end{array}$ & & $\begin{array}{l}0.714 \pm 0.104^{\mathrm{a}} \\
(17.731 \pm 2.593) \\
\end{array}$ & & $6.17 \pm 1.60^{\mathrm{a}}$ & & $0.293 \pm 0.013 b, c$ & \\
\hline \multirow{3}{*}{ Fe-control } & 45 & 1 & $\mathrm{C} 1$ & 6 & $\begin{array}{l}158.83 \pm 43.65 \\
(8.816 \pm 2.423)\end{array}$ & & $\begin{array}{r}0.575 \pm 0.095^{\mathrm{a}} \\
(14.279 \pm 2.370)\end{array}$ & & $5.73 \pm 2.17^{a}$ & & $0.300 \pm 0.016^{\mathrm{b}, \mathrm{c}}$ & \\
\hline & 45 & 50 & C50 & 6 & $\begin{array}{l}179.50 \pm 48.09 \\
(9.964 \pm 2.669) \\
\end{array}$ & & $\begin{array}{l}0.614 \pm 0.100^{\mathrm{a}} \\
(15.235 \pm 2.480) \\
\end{array}$ & & $6.77 \pm 2.09^{a}$ & & $0.293 \pm 0.013 \mathrm{~b}, \mathrm{c}$ & \\
\hline & 45 & 500 & C500 & 6 & $\begin{array}{r}192.33 \pm 43.83 \\
(10.676 \pm 2.433)\end{array}$ & & $\begin{array}{l}0.644 \pm 0.137 \text { a } \\
(15.988 \pm 3.395)\end{array}$ & & $7.86 \pm 3.56^{\mathrm{a}}$ & & $0.289 \pm 0.014^{\mathrm{b}}$ & \\
\hline \multirow{3}{*}{ Fe-oversupply } & 180 & 1 & H1 & 6 & $\begin{array}{l}162.00 \pm 59.39 \\
(8.992 \pm \pm 3.296)\end{array}$ & & $\begin{array}{r}0.457 \pm 0.044^{\mathrm{a}} \\
(11.355 \pm 1.095)\end{array}$ & & $4.56 \pm 1.74^{\mathrm{a}}$ & & $0.309 \pm 0.016^{b, c}$ & \\
\hline & 180 & 50 & H50 & 6 & $\begin{array}{l}126.83 \pm 15.90 \\
(7.040 \pm 0.883)\end{array}$ & & $\begin{array}{c}0.487 \pm 0.061^{\mathrm{a}} \\
(12.086 \pm 1.522)\end{array}$ & & $3.75 \pm 0.39^{\mathrm{a}}$ & & $0.315 \pm 0.005^{c}$ & \\
\hline & 180 & 500 & $\mathrm{H} 500$ & 6 & $\begin{array}{l}140.50 \pm 18.92 \\
(7.799 \pm 1.050)\end{array}$ & & $\begin{array}{l}0.449 \pm 0.037 \mathrm{a} \\
(11.152 \pm 0.910)\end{array}$ & & $3.88 \pm 0.70^{\mathrm{a}}$ & & $0.314 \pm 0.008^{c}$ & \\
\hline
\end{tabular}

Note: The values which do not have the same superscript letter are significantly different $(p<0.05)$; NS: no significant effect; SD: standard deviation. 
As the Fe(III) level in the rats' diets increased, the insulin concentration decreased. In comparison with the control Fe level in the diet, Fe(III) deficiency significantly increased the insulin concentration (almost two times-108.5\%) $(p<0.001)$, whereas Fe excess slightly reduced it. In comparison with the recommended $\mathrm{Cr}$ (III) level in the diet (1 mg/kg), Cr(III) supplementation at doses of 50 and $500 \mathrm{mg} / \mathrm{kg}$ increased the insulin concentration by $42.3 \%$ and $45.7 \%$, respectively. There was also a significant interactive effect of the experimental factors on the serum insulin concentration. The highest insulin concentration was noted in the group of rats fed the Fe-deficient diet with the recommended $\mathrm{Cr}$ (III) level, as compared with the other groups. In comparison with the control group, this concentration was almost three times higher $(2.292 \pm 0.688$ vs. $0.575 \pm 0.095 \mathrm{ng} / \mathrm{mL})(p<0.001)$. Moreover, some tendencies were observed. In the Fe deficit groups the additional $\mathrm{Cr}$ (III) supplementation at doses of 50 and $500 \mathrm{mg} / \mathrm{kg}$ reduced the serum insulin levels. The Cr(III) supplementation in the groups with the recommended Fe level slightly increased the serum insulin level and in the groups with Fe excess supply did not have a definite direction of this change.

For the HOMA-IR index, it was found that both an increase Fe supply in the diet $(p<0.001)$ and $\mathrm{Cr}(\mathrm{III})$ doses $(p<0.001)$ decreased the value of this parameter. In the case of different Fe levels in the diet, a significant difference was found in the values of this index between Fe deficit and Fe excess groups (11.72 \pm 8.98 vs. $4.06 \pm 1.10)$. However, these values were not significantly different from the control group ( $6.79 \pm 2.68$ ). In turn, the $\mathrm{Cr}$ (III) doses of 50 and $500 \mathrm{mg} / \mathrm{kg} \mathrm{Cr}$ (III) reduced the HOMA-IR index value by $42.0 \%$ and $43.3 \%$, respectively, as compared with the group with the recommended amount of $\mathrm{Cr}(\mathrm{III})$ in the rodent diet. However, only the highest dose resulted in a statistically significant effect. The combined effect of the experimental factors on the index was also significant. The group of rats fed the Fe-deficient diet and $\mathrm{Cr}(\mathrm{III})$ at the control level had a significantly higher HOMA-IR index value than the other experimental groups. In comparison with the control group, this was an increase of $272 \%(21.30 \pm 10.09$ vs. $5.73 \pm 2.17)$. There were some noticeable trends. In the Fe(III)-deficient and $\mathrm{Fe}(\mathrm{III})$-excess groups $\mathrm{Cr}$ (III) supplementation decreased the HOMA-IR index value. Its value increased slightly in the group fed the diet with the recommended Fe level $(45 \mathrm{mg} / \mathrm{kg})$.

As the Fe(III) supply in the diet increased, so did the value of the Quicki index. The lowest value was observed in the Fe-deficient groups. It was significantly higher in the groups with the recommended amount of Fe(III) in the diet and the highest in the groups with Fe(III) excess. The dietary doses of $\mathrm{Cr}$ (III) 50 and $500 \mathrm{mg} / \mathrm{kg}$ increased the Quciki index value, but the effect was statistically significant only for the dose of $500 \mathrm{mg} / \mathrm{kg}$, as compared with the recommended amount of this element in the diet. The combined effect of different Fe(III) supply with diet and simultaneous $\mathrm{Cr}$ (III) supplementation on Quciki index has also been found. There were significantly lower values of this index in the $\mathrm{Fe}$ (III)-deficient groups than in the groups with the adequate and excessive Fe(III) levels, which were supplemented with the same amounts of $\mathrm{Cr}$ (III). The simultaneous $\mathrm{Cr}$ (III) supplementation of the rats in the $\mathrm{Fe}$ (III)-deficient and $\mathrm{Fe}$ (III)-excess groups in the diet increased the values of this index. However, it tended to decrease in the groups with the recommended iron level in the diet.

Ghrelin levels were not affected by Fe(III) in diet (Table 4). However, $\mathrm{Cr}$ (III) supplementation at doses of 50 and $500 \mathrm{mg} / \mathrm{kg}$ reduced the level of this hormone by $20 \%$ and $19 \%$, respectively. The serum ghrelin concentration was also affected by the interaction of Fe(III) levels and high dietary doses of $\mathrm{Cr}$ (III). There were significantly lower levels of this hormone in the Fe(III)-deficient and Fe(III)-excess groups supplemented with $\mathrm{Cr}$ (III) at a dose of $50 \mathrm{mg} / \mathrm{kg}$ and in the group with the recommended Fe level supplemented with $\mathrm{Cr}$ (III) at a dose of $500 \mathrm{mg} / \mathrm{kg}$, as compared with the control group, where the level of ghrelin was the highest.

The experimental factors did not independently or in combination have any significant effect on the leptin, AST, and ALT concentrations in the rats (Table 4). 
However, as the Fe(III) levels in the diet increased, the ALP levels decreased. There were significantly lower ALP levels in the rats fed the Fe-deficient diet than in the control or Fe-excess groups. The $\mathrm{Cr}(\mathrm{III})$ supplementation at a dose of $50 \mathrm{mg} / \mathrm{kg}$ reduced the value of this parameter by $12.8 \%$, whereas at a dose of $500 \mathrm{mg} / \mathrm{kg}$ it was similar to the control group. There was no interactive effect of the experimental factors on this parameter.

As can been seen in Table 5, neither different Fe(III) levels in the diet nor high Cr(III) doses (independently or in combination) caused significant changes in the parameters of renal function, such as concentrations total protein (TP), creatinine (Crea), and urea (BUN).

In addition, neither Fe deficiency nor its excess in the diet combined with $\mathrm{Cr}$ (III) supplementation resulted in a significant interaction effect on the Wistar rats' lipid profile, except the HDL-cholesterol (HDL-C) level (Table 6). Both the Fe(III) deficit and excess in the diet increased the HDL-C concentration in the female rats. Although $\mathrm{Cr}$ (III) supplementation on its own had no effect, there was a significant interactive effect of $\mathrm{Cr}(\mathrm{III})$ and $\mathrm{Fe}(\mathrm{III})$ on this parameter. The HDL-C level was significantly lower in the rats fed the diet with the adequate amount of Fe and supplemented with $\mathrm{Cr}(\mathrm{III})$ at a dose of $50 \mathrm{mg} / \mathrm{kg}$, as compared with the animals fed the diet with an excessive Fe supply and the control $\mathrm{Cr}$ (III) level. There were no significant changes among other groups. 
Table 4. The effects of the Fe(III) and Cr(III) levels in the diet on the concentrations of selected hormones and enzymes in rats.

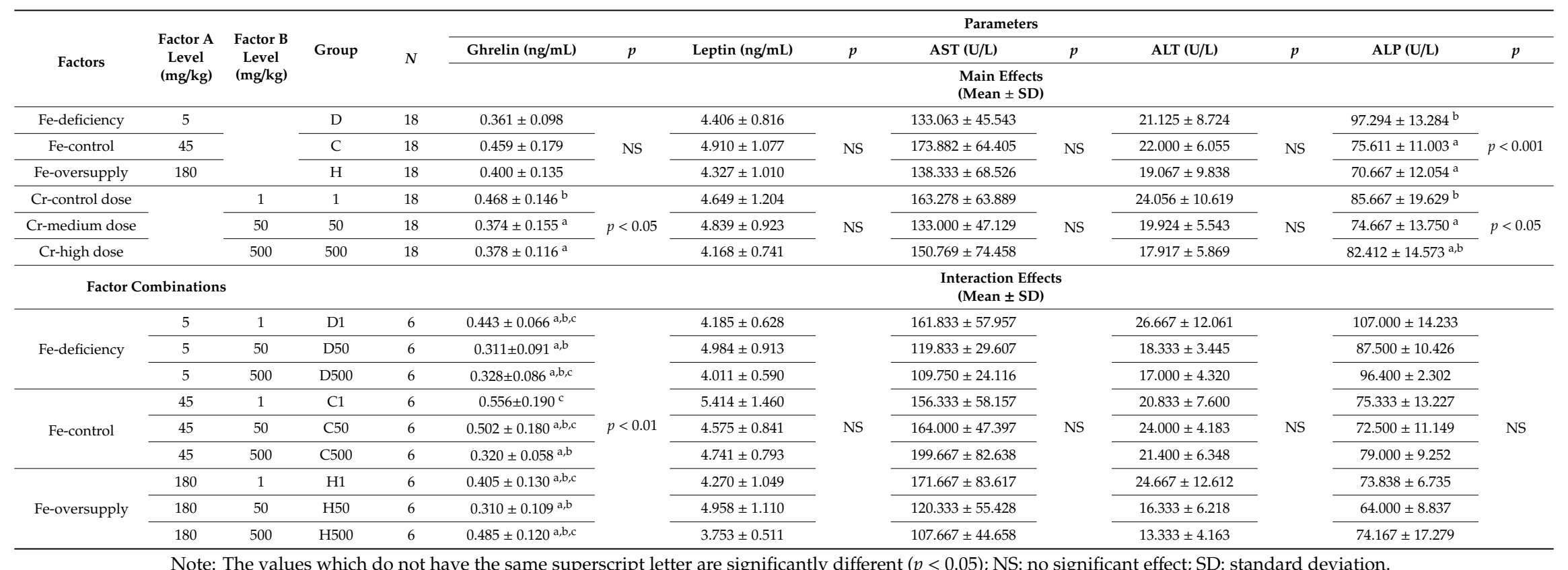

Note: The values which do not have the same superscript letter are significantly different $(p<0.05)$; NS: no significant effect; SD: standard deviation. 
Table 5. The effects of the Fe(III) and Cr(III) levels in the diet on the concentrations of selected biochemical parameters in rats.

\begin{tabular}{|c|c|c|c|c|c|c|c|c|c|c|}
\hline \multirow{3}{*}{ Factors } & \multirow{3}{*}{$\begin{array}{l}\text { Factor A } \\
\text { Level } \\
(\mathrm{mg} / \mathrm{kg})\end{array}$} & \multirow{3}{*}{$\begin{array}{l}\text { Factor B } \\
\text { Level } \\
(\mathrm{mg} / \mathrm{kg})\end{array}$} & \multirow{3}{*}{ Group } & \multirow{3}{*}{$N$} & \multicolumn{6}{|c|}{ Parameters } \\
\hline & & & & & $\begin{array}{l}\text { Total Protein (TP) } \\
\text { Concentration } \\
(\mathrm{g} / \mathrm{dL})\end{array}$ & $p$ & $\begin{array}{c}\text { Creatinine (Crea) } \\
\text { Concentration (mg/dL) }\end{array}$ & $p$ & $\begin{array}{c}\text { Urea (BUN) } \\
\text { Concentration (mg/dL) }\end{array}$ & $p$ \\
\hline & & & & & \multicolumn{6}{|c|}{$\begin{array}{l}\text { Main Effects } \\
\text { (Mean } \pm \text { SD) }\end{array}$} \\
\hline Fe-deficiency & 5 & & $\mathrm{D}$ & 18 & $6.383 \pm 0.215$ & \multirow{3}{*}{ NS } & $0.509 \pm 0.053^{\mathrm{a}, \mathrm{b}}$ & \multirow{3}{*}{$p<0.05$} & $44.000 \pm 9.266$ & \multirow{3}{*}{ NS } \\
\hline Fe-control & 45 & & C & 18 & $6.456 \pm 0.273$ & & $0.537 \pm 0.071^{b}$ & & $40.750 \pm 8.745$ & \\
\hline Fe-oversupply & 180 & & $\mathrm{H}$ & 18 & $6.382 \pm 0.227$ & & $0.486 \pm 0.037^{\mathrm{a}}$ & & $38.333 \pm 7.104$ & \\
\hline Cr-control dose & & 1 & 1 & 18 & $6.361 \pm 0.212$ & \multirow{3}{*}{ NS } & $0.523 \pm 0.061$ & \multirow{3}{*}{ NS } & $43.588 \pm 10.087$ & \multirow{3}{*}{ NS } \\
\hline Cr-medium dose & & 50 & 50 & 18 & $6.394 \pm 0.277$ & & $0.509 \pm 0.065$ & & $38.625 \pm 7.429$ & \\
\hline Cr-high dose & & 500 & 500 & 18 & $6.467 \pm 0.222$ & & $0.501 \pm 0.050$ & & $40.412 \pm 7.500$ & \\
\hline \multicolumn{5}{|c|}{ Factor Combinations } & \multicolumn{6}{|c|}{$\begin{array}{l}\text { Interaction Effects } \\
(\text { Mean } \pm \text { SD) }\end{array}$} \\
\hline \multirow{3}{*}{ Fe-deficiency } & 5 & 1 & D1 & 6 & $6.383 \pm 0.183$ & \multirow{9}{*}{ NS } & $0.532 \pm 0.061$ & \multirow{9}{*}{ NS } & $40.600 \pm 12.818$ & \multirow{9}{*}{ NS } \\
\hline & 5 & 50 & D50 & 6 & $6.333 \pm 0.250$ & & $0.513 \pm 0.062$ & & $44.400 \pm 7.829$ & \\
\hline & 5 & 500 & D500 & 6 & $6.433 \pm 0.234$ & & $0.482 \pm 0.021$ & & $46.500 \pm 7.609$ & \\
\hline & 45 & 1 & $\mathrm{C} 1$ & 6 & $6.317 \pm 0.232$ & & $0.528 \pm 0.078$ & & $45.500 \pm 10.895$ & \\
\hline Fe-control & 45 & 50 & C50 & 6 & $6.500 \pm 0.358$ & & $0.545 \pm 0.075$ & & $37.600 \pm 7.127$ & \\
\hline & 45 & 500 & C500 & 6 & $6.550 \pm 0.187$ & & $0.537 \pm 0.071$ & & $38.200 \pm 5.762$ & \\
\hline \multirow{3}{*}{ Fe-oversupply } & 180 & 1 & H1 & 6 & $6.383 \pm 0.248$ & & $0.510 \pm 0.049$ & & $44.167 \pm 7.859$ & \\
\hline & 180 & 50 & H50 & 6 & $6.340 \pm 0.207$ & & $0.462 \pm 0.013$ & & $34.667 \pm 4.761$ & \\
\hline & 180 & 500 & H500 & 6 & $6.417 \pm 0.256$ & & $0.483 \pm 0.023$ & & $36.167 \pm 4.956$ & \\
\hline
\end{tabular}

Note: The values which do not have the same superscript letter are significantly different $(p<0.05)$; NS: no significant effect; SD: standard deviation. 
Table 6. The effects of the Fe(III) and Cr(III) levels in the diet on the lipid profile in rats.

\begin{tabular}{|c|c|c|c|c|c|c|c|c|c|c|c|c|}
\hline \multirow{3}{*}{ Factors } & \multirow{3}{*}{$\begin{array}{l}\text { Factor A Level } \\
\quad(\mathrm{mg} / \mathrm{kg})\end{array}$} & \multirow{3}{*}{$\begin{array}{l}\text { Factor B Level } \\
\quad(\mathrm{mg} / \mathrm{kg})\end{array}$} & \multirow{3}{*}{ Group } & \multirow{3}{*}{$N$} & \multicolumn{8}{|c|}{ Parameters } \\
\hline & & & & & $\begin{array}{l}\text { Triglycerides (TG) } \\
\text { Concentration } \\
\text { (mg/dL) }\end{array}$ & $p$ & $\begin{array}{l}\text { Total Cholesterol } \\
\text { Concentration } \\
(\mathrm{mg} / \mathrm{dL})\end{array}$ & $p$ & $\begin{array}{l}\text { LDL Cholesterol } \\
\text { (mg/dL) }\end{array}$ & $p$ & $\begin{array}{l}\text { HDL Cholesterol } \\
\text { (mg/dL) }\end{array}$ & $p$ \\
\hline & & & & & \multicolumn{8}{|c|}{$\begin{array}{l}\text { Main Effects } \\
\text { (Mean } \pm \text { SD) }\end{array}$} \\
\hline Fe-deficiency & 5 & & $\mathrm{D}$ & 18 & $38.375 \pm 11.372$ & \multirow{3}{*}{ NS } & $84.278 \pm 11.876$ & \multirow{3}{*}{ NS } & $44.193 \pm 7.771$ & \multirow{3}{*}{ NS } & $29.205 \pm 1.893^{b}$ & \multirow{3}{*}{$p<0.05$} \\
\hline Fe-control & 45 & & $\mathrm{C}$ & 18 & $46.118 \pm 10.879$ & & $81.333 \pm 12.049$ & & $44.858 \pm 10.884$ & & $27.634 \pm 2.272^{\mathrm{a}}$ & \\
\hline Fe-oversupply & 180 & & $\mathrm{H}$ & 18 & $43.000 \pm 9.507$ & & $90.833 \pm 20.709$ & & $48.318 \pm 11.981$ & & $29.219 \pm 2.683^{b}$ & \\
\hline Cr-control dose & & 1 & 1 & 18 & $44.647 \pm 11.113$ & \multirow{3}{*}{ NS } & $87.889 \pm 27.357$ & \multirow{3}{*}{ NS } & $44.737 \pm 12.250$ & \multirow{3}{*}{ NS } & $29.428 \pm 2.830$ & \multirow{3}{*}{ NS } \\
\hline Cr-medium dose & & 50 & 50 & 18 & $41.412 \pm 11.125$ & & $80.278 \pm 14.776$ & & $43.155 \pm 9.330$ & & $27.878 \pm 2.126$ & \\
\hline Cr-high dose & & 500 & 500 & 18 & $41.625 \pm 10.682$ & & $88.278 \pm 14.228$ & & $48.491 \pm 8.589$ & & $28.515 \pm 1.950$ & \\
\hline \multicolumn{5}{|c|}{ Factors Combinations } & \multicolumn{8}{|c|}{$\begin{array}{l}\text { Interaction Effects } \\
\text { (Mean } \pm \text { SD) }\end{array}$} \\
\hline \multirow{3}{*}{ Fe-deficiency } & 5 & 1 & D1 & 6 & $38.000 \pm 7.714$ & \multirow{9}{*}{ NS } & $90.000 \pm 10.526$ & \multirow{9}{*}{ NS } & $43.613 \pm 2.867$ & \multirow{9}{*}{ NS } & $30.586 \pm 1.151^{\mathrm{a}, \mathrm{b}}$ & \multirow{9}{*}{$p<0.05$} \\
\hline & 5 & 50 & D50 & 6 & $36.500 \pm 8.939$ & & $77.000 \pm 13.221$ & & $42.223 \pm 10.164$ & & $28.370 \pm 2.210^{\mathrm{a}, \mathrm{b}}$ & \\
\hline & 5 & 500 & D500 & 6 & $41.000 \pm 17.649$ & & $85.833 \pm 9.390$ & & $46.550 \pm 7.831$ & & $28.750 \pm 1.712^{a, b}$ & \\
\hline \multirow{3}{*}{ Fe-control } & 45 & 1 & $\mathrm{C} 1$ & 6 & $47.167 \pm 13.029$ & & $80.000 \pm 14.873$ & & $43.348 \pm 13.019$ & & $27.218 \pm 3.007^{\mathrm{a}, \mathrm{b}}$ & \\
\hline & 45 & 50 & $\mathrm{C} 50$ & 6 & $48.800 \pm 13.971$ & & $73.167 \pm 3.251$ & & $36.756 \pm 3.855$ & & $26.488 \pm 1.410^{\mathrm{a}}$ & \\
\hline & 45 & 500 & C500 & 6 & $42.833 \pm 5.601$ & & $90.833 \pm 8.448$ & & $53.120 \pm 6.883$ & & $29.197 \pm 1.345^{\mathrm{a}, \mathrm{b}}$ & \\
\hline \multirow{3}{*}{ Fe-oversupply } & 180 & 1 & H1 & 6 & $47.667 \pm 10.727$ & & $93.667 \pm 23.922$ & & $47.945 \pm 18.446$ & & $30.920 \pm 2.368^{\mathrm{b}}$ & \\
\hline & 180 & 50 & H50 & 6 & $40.167 \pm 8.635$ & & $90.667 \pm 18.811$ & & $52.553 \pm 5.148$ & & $29.348 \pm 2.031^{a, b}$ & \\
\hline & 180 & 500 & H500 & 6 & $40.800 \pm 8.585$ & & $88.167 \pm 22.666$ & & $44.458 \pm 10.752$ & & $27.416 \pm 2.644^{\mathrm{a}, \mathrm{b}}$ & \\
\hline
\end{tabular}

Note: The values which do not have the same superscript letter are significantly different $(p<0.05)$; NS: no significant effect; SD: standard deviation. 


\section{Discussion}

Disturbed Fe homeostasis may be related to the etiology of some chronic diseases, including anemia [24], diabetes [50], cancer [51,52], and cardiovascular diseases [17]. Both the deficiency and accumulation of some microelements may stimulate a different pathway of their metabolism and affect the metabolism of other elements, which may result in the development of these diseases. Interactions between elements may also stimulate many other disorders [53]. Currently, more and more attention is paid to the potential role of chromium(III) and iron in glucose metabolism and the development of diabetes $[1,3]$.

To our knowledge, this is the first time that the interactive effect of $\mathrm{Cr}$ (III) supplementation and different Fe(III) levels in the diet on glucose metabolism and insulin resistance indexes as well as the HDL-C concentration in Wistar rats were identified. We suppose that new and potentially relevant findings appeared from this study. Usually, these factors were analysed separately in the context of the development of diabetes. As our research shows, the interactions between these elements should be taken into account in the development of carbohydrate disorders. Our results suggest that the disturbed homeostasis of both Fe and Cr(III) (deficiency/excess) disrupts the carbohydrate metabolism that may lead to diabetes. Relations between trace element levels and the prevalence of previously undiagnosed type 2 diabetes mellitus (T2DM) were studied by Hansen et al. [1]. Their results suggested a possible role among others of chromium and iron as well as other elements $(\mathrm{Br}, \mathrm{Cd}, \mathrm{Ni}, \mathrm{Ag}$, and $\mathrm{Zn})$ in the development of T2DM. In addition, Zhou et al. [3] analysed the $\mathrm{Cr}$ and Fe concentrations in the serum and urine of patients with impaired fasting glucose (IFG), impaired glucose tolerance (IGT), type 1 diabetes mellitus (T1DM), and type 2 diabetes mellitus (T2DM). They observed that the serum Cr levels were reduced in T2DM and the negative trend appeared in IFG, IGT, and T1DM. However, there were no significant differences in the serum Fe levels between these groups. They noticed a positive correlation between the serum $\mathrm{Cr}$ concentration and serum Fe concentration in T2DM. Meanwhile, these relations in IFG, IGT, and T1DM were not significant.

According to Ahmed et al. [2], iron deficiency significantly affected the glycaemic status of diabetic patients with iron deficiency anemia (IDA) by increasing the fasting blood glucose (FBG) and glycated hemoglobin (HbA1c) levels; however, Fe supplementation normalised these parameters. The researchers observed that IDA was highly correlated with T2DM in these patients. Similarly, Krisai et al. [20] observed that the markers of insulin resistance (insulin, FBG, HbA1c, HOMA-IR) were strongly correlated with the parameters of iron metabolism (plasma ferritin and transferrin saturation (TSAT) levels) in young and healthy subjects. However, it was suggested that Fe metabolism was mainly associated with insulin resistance and, to a lesser extent, with blood glucose concentration. These data confirm our observations on the animal model. We noticed that both Fe deficiency and oversupply led to a decrease in plasma glucose concentration in female rats. Moreover, as dietary Fe levels increased, insulin concentrations and HOMA-IR index decreased and Quicki index increased. Another study demonstrated that a low Fe supply in diet $(3 \mathrm{mg} / \mathrm{kg})$ decreased serum triglycerides and cholesterol concentrations in healthy and diabetic male rats but also improved insulin and glucose tolerance in healthy Wistar rats [54].

Iron is a transition element, which may act as an oxidant and produce reactive oxygen species (ROS). Most evidence supports the hypothesis that both Fe deficiency and overload cause the overproduction of free radicals. Thus, it causes tissue damage and increases oxidative stress [28-30]. According to Vieyra-Reyes et al. [30], the iron deficiency promotes oxidative stress, depending on the rat's gender and age. However, at birth and late adolescence there was more damage to the plasma, liver, and more so the brain of male than female Wistar rats.

Furthermore, increased Fe accumulation affects insulin synthesis and secretion by pancreatic $\beta$-cells. The accumulation of Fe in the liver may cause insulin resistance by interfering with the ability of insulin to inhibit hepatic glucose production [1,29,55-58]. Another hypothesis suggests that insulin may facilitate Fe accumulation by redistributing transferrin receptors to the cell surface as well as by cellular uptake and stimulation of ferritin synthesis $[20,59,60]$. Although iron uptake is widely 
regulated, an Fe excess in the diet may increase Fe levels in tissues more than it is necessary to maintain normal erythropoiesis and metabolic function [50]. The data obtained in our study confirmed these observations, where increased tissue levels of this element were noticed [61].

Silvia et al. [62] observed that iron excess increased serum triglycerides (TG) and decreased serum glucose and $\mathrm{HbA} 1 \mathrm{c}$ levels irrespective of the diet (standard or hyperlipidaemic). However, it did not affect the serum T-Chol concentration as well as malondialdehyde (MDA) and total antioxidants levels. These authors suggested that iron excess may have modified rats' lipid metabolism, further changed glucose homeostasis, and increased the serum triglycerides level but not the cholesterol level. In our study, it was noticed that both iron deficiency and excess increased only HDL-C levels, but they did not cause significant changes in other elements of the lipid profile (T-Chol, LDL-C, TG).

Supplementation with organic $\mathrm{Cr}$ (III) compounds is part of an attractive strategy of alleviating insulin resistance. For this reason, trivalent chromium complexes may act as a relevant function in the prevention of diabetes, metabolic syndrome, and related diseases. There are many suggestions about the molecular mechanisms of chromium in alleviating insulin resistance. One of them says that $\mathrm{Cr}$ (III) compounds potentiate the action of insulin. Our study confirmed this fact. Another says that it enhances the insulin signalling pathway by improving the tyrosine phosphorylation of insulin and the insulin receptor tyrosine kinase activity as well AMPK activity. Another one says that $\mathrm{Cr}$ (III) weakens the negative regulators of the insulin signalling pathway. According to another suggestion, chromium upregulates cellular glucose uptake by increasing GLUT-4 translocation to the cell surface and reduces oxidative stress in animals with insulin resistance [1,21,63-66]. Pala et al. [67] observed that CrPic supplementation at a dose of $400 \mu \mathrm{g}$ elemental $\mathrm{Cr} / \mathrm{kg}$ of diet reduced the blood glucose, T-Chol, TG, and MDA levels and improved the GLUT-2 and GLUT-4 transporters levels in the liver and muscle of rats with chronic and acute exercise training. Another study showed that dietary chromium(III) histidinate (CrHis) supplementation decreased the glucose, T-Chol, and TG levels but increased the HDL-C level. Moreover, these effects were more efficient when $\mathrm{CrHis}$ was combined with biotin and exercises. However, there was no significant change in the AST and ALT levels in any of the experimental groups. The $\mathrm{Cr}$ (III) alone and in combination with biotin and exercises also improved the protein expression levels of IRS-1, PPAR- $\gamma$, and NF- $\mathrm{B}$ in the liver and muscle of Wistar rats [68]. Jovanović et al. [69] found that the treatment with chromium-enriched yeast significantly increased IR $\beta$, pIRS- 1Tyr632, pAkt Ser473, GLUT4, and AMPK protein expression in the insulin signaling pathway. In addition, they observed increased insulin sensitivity and better utilization of glucose in a group of Holstein calves after 70 days of $\mathrm{Cr}(\mathrm{III})$ supplementation. Chromium(phenylalanine $)_{3}\left[\mathrm{Cr}(\mathrm{pa})_{3}\right]$ supplementation of obese mice at a dose $150 \mu \mathrm{g} \mathrm{Cr} / \mathrm{kg} / \mathrm{b} . w$. for six weeks improved their glucose tolerance, as compared with untreated mice. The $\mathrm{Cr}(\mathrm{pa})_{3}$ complex enhanced insulin-stimulated phosphorylation of Akt in a timeand concentration-dependent way without changing the phosphorylation of insulin receptors [70].

Feng at al. [71] observed that long-term administration of $\mathrm{Cr}$ (III) malate to Sprague-Dawley rats at daily doses of 10.0, 15.0, and $20.0 \mu \mathrm{g} / \mathrm{kg}$ b.w. reduced the concentration of T-Chol, LDL-C, and TAG only in the male but not female animals. However, it did not affect carbohydrate metabolism parameters such as FBG, serum insulin concentrations, IR-index and related enzymes (G6PD and GCK level), and other biochemical indices (ALT, AST, ALP, TP, BUN, Crea) in rodents of both gender. Seif [72] noted that Cr supplementation of hypercholesterolemic rats at a dose of $200 \mu \mathrm{g} / \mathrm{day} \mathrm{CrPic}$ for 10 weeks improved their lipid profile and reduced excessive platelet aggregation, mainly by lowering the cholesterol concentration.

In turn, the addition of chromium chloride $\left(\mathrm{CrCl}_{3}\right)$ at doses 200 and $400 \mu \mathrm{g} / \mathrm{kg}$ to the diet of rabbits (pregnant rabbits, their offspring and their young rabbits) did not affect the serum T-Chol, TG, $\mathrm{TP}$, and urea concentrations in all generations [73]. Zhang et al. [74] observed that the maternal low chromium level increased the serum TG, LDL-C, leptin, TNF- $\alpha$, and IL-6 levels in offsprings at eight months of age. However, the normalization of the offspring diet might not be able to reverse all these effects. The authors explained this by the disturbance of the PPAR $\gamma$ signalling pathway in the adipose tissue, which regulates adipocyte differentiation, adipogenesis, and lipid metabolism. 
A single dose of $2000 \mathrm{mg} / \mathrm{kg} / \mathrm{b}$.w. of the $\mathrm{Cr} 3$ complex did not change the glucose concentration and lipid profile in both healthy male and female Wistar rats during a 14-day experiment [36]. In addition, high doses of the $\mathrm{Cr} 3$ complex (100-1000 mg/kg diet) given to female Wistar rats for six weeks were not effective on glucose levels and lipid profile (except the TAG level), hepatic enzymes activity (ALT, AST) and selected poisoning indices (TP, Crea, and BUN concentrations) [75]. Five-week supplementation of diabetic male rats with the $\mathrm{Cr} 3$ complex at doses of 10 and $50 \mathrm{mg} \mathrm{Cr} / \mathrm{kg}$ diet did not significantly change their blood glucose concentration but improved their insulin sensitivity (HOMA-IR index) and decreased the serum TG, T-Chol, and LDL-C concentrations [76]. Similarly, Doddigrala et al. [77] noticed that chromium picolinate (CrPic) $(1.4 \mu \mathrm{g} /$ day) and melatonin (Mel) $(200 \mu \mathrm{g} / \mathrm{day})$ administered alone or in a combination significantly lowered the HOMA-IR index, T-Chol and TG levels but increased the HDL-C level. In this way, it prevented insulin resistance and T2DM in male Wistar rats fed a high carbohydrate diet (HCD). The supplementation of mice fed a high-fat diet (HFD) with a novel Grifola frondosa polysaccharide-chromium(III) complex (GFP-Cr(III)) at daily doses of 3 and $9 \mathrm{mg}$ $\mathrm{Cr}(\mathrm{III}) / \mathrm{kg} / \mathrm{b}$.w. for eight weeks resulted in hyperglycaemic effect and prevented hyperlipidaemia and streptozotocin (STZ)-induced diabetes [78].

Other studies showed that two-week administration of different $\mathrm{Cr}(\mathrm{III})$ complexes, such as chromium methionine (CrMet), chromium rutin complex (CrRC), chromium folate complex (CrFC), and chromium stachyose complex (CrSC) to mice with alloxan-induced diabetes had beneficial effects on their glucose and lipid metabolism and resulted in hepatoprotective effect $[79,80]$. The observed inconsistencies may be related to the different forms, levels, and the time of supplementation with $\mathrm{Cr}$ (III) compounds, as well as the sex and health of the animals used in the research. Analytical problems related to biomarkers of $\mathrm{Cr}$ deficiency in the body also pose some difficulties in the interpretation of the obtained results.

Further research is necessary to investigate the role of selected elements and their interaction and molecular mechanisms of actions as well in the development of diabetes, metabolic syndrome, and related diseases.

\section{Conclusions}

In view of the above results, it seems that the high dietary doses of $\mathrm{Cr}(\mathrm{III})$, independently and in combination with diversified Fe(III) content in the diet, affected the carbohydrate metabolism and insulin resistance indexes, but they did not affect the lipid profile (except HDL-C) or most of the biochemical parameters of healthy rats.

The study proved the role of $\mathrm{Fe}$ and $\mathrm{Cr}(\mathrm{III})$ and their mutual interactions on disturbances inter alia carbohydrates metabolism. The obtained results suggested that iron deficient fed animals led to insulin resistance; however, an effect is attenuated by $\mathrm{Cr}$ (III) supplementation at high doses. For this reason, further research is necessary to investigate the role of selected elements and their interaction in the development of diabetes, metabolic syndrome, and related diseases.

Author Contributions: H.Z.S. and R.W.W. conceptualization; H.Z.S., E.K. and R.W.W. methodology; H.Z.S. and R.W.W. investigation; H.Z.S. writing - original draft preparation; H.Z.S. writing-review and editing; H.Z.S. project supervision and administration; H.Z.S. funding acquisition. All authors have read and agreed to the published version of the manuscript.

Funding: These studies were supported with the faculty funds for the development of young scientists (Nos. 507-786-29 and 507.786.44) from the Poznan University of Life Sciences. The publication co-finansed within the framework of Ministry of Science and Higher Education programme as "Regional Initiative Excellence" in years 2019-2022, project number 005/RID/2018/19.

Acknowledgments: The authors would like to thank Daria Wieczorek from the Department of Technology and Instrumental Analysis, Poznan University of Economics, Poland, for preparing the Cr3 complex and Malgorzata Tubacka from the Institute Human Nutrition and Dietetics, Poznan University of Life Sciences, Poznan, for helping to conduct the experiment.

Conflicts of Interest: The authors declare no conflict of interest. 


\section{References}

1. Hansen, A.F.; Simić, A.; Åsvold, B.O.; Romundstad, P.R.; Midthjell, K.; Syversen, T.; Flaten, T.P. Trace elements in early phase type 2 diabetes mellitus-A population-based study. The HUNT study in Norway. J. Trace Elem. Med. Biol. 2017, 40, 46-53. [CrossRef]

2. Ahmed, A.S.; Elgharabawy, R.M.; Al-Najjar, A.H.; Al-Abdullatif, M.H.; Al-Abdllatif, M.A.; Al-Mogbel, T.A. Impact of iron deficiency anemia treatment on type 2 diabetic complications. Biochem. Mol. Biol. J. 2019, 5, $1-6$.

3. Zhou, Q.; Guo, W.; Jia, Y.; Xu, J. Comparison of chromium and iron distribution in serum and urine among healthy people and prediabetes and diabetes patients. Biomed Res. Int. 2019, 2019, 1-8. [CrossRef] [PubMed]

4. Basuli, D.; Stevens, R.G.; Torti, F.M.; Torti, S.V. Epidemiological associations between iron and cardiovascular disease and diabetes. Front. Pharmacol. 2014, 5, 1-10. [CrossRef]

5. Xiao, C.; Lei, X.; Wang, Q.; Du, Z.; Jiang, L.; Chen, S. Effects of a tripeptide iron on iron-deficiency anemia in rats. Boiol. Trace Elem. Res. 2016, 169, 211-217. [CrossRef] [PubMed]

6. Gkouvatsos, K.; Papanikolaou, G.; Pantopoulos, K. Regulation of iron transport and the role of transferrin. Biochim. Biophys. Acta Gen. Subj. 2012, 1820, 188-202. [CrossRef]

7. Auerbach, M.; Adamson, J.W. How we diagnose and treat iron deficiency anemia. Am. J. Hematol. 2016, 91, 31-38. [CrossRef] [PubMed]

8. Kassebaum, N.J.; Jasrasaria, R.; Naghavi, M.; Wulf, S.K.; Johns, N.; Lozano, R.; Regan, M.; Weatherall, D.; Chou, D.P.; Eisele, T.P.; et al. Red cells, iron, and erythropoiesis. A systematic analysis of global anemia burden from 1990 to 2010. Blood J. 2014, 123, 615-625. [CrossRef]

9. Naigamwalla, D.Z.; Webb, J.A.; Giger, U. Iron deficiency anemia. Can. Vet. J. 2012, 53, 250-256.

10. Bjørklund, G.; Aaseth, J.; Skalny, A.V.; Suliburska, J.; Skalnaya, M.G.; Nikonorov, A.A.; Tinkov, A.A. Interactions of iron with manganese, zinc, chromium, and selenium as related to prophylaxis and treatment of iron deficiency. J. Trace Elem. Med. Biol. 2017, 41, 41-53. [CrossRef]

11. Petry, N.; Olofin, I.; Hurrell, R.F.; Boy, E.; Wirth, J.P.; Moursi, M.; Angel, M.D.; Rohner, F. The proportion of anemia associated with iron deficiency in low, medium, and high human development index countries: A systematic analysis of national surveys. Nutrients 2016, 8, 693. [CrossRef] [PubMed]

12. Smith, M.R.; Golden, C.D.; Myers, S.S. Potential rise in iron deficiency due to future anthropogenic carbon dioxide emissions. GeoHealth 2017, 1, 248-257. [CrossRef] [PubMed]

13. Park, C.Y.; Chung, J.; Koo, K.-O.; Kim, M.S.; Han, S.N. Hepatic iron storage is related to body adiposity and hepatic inflammation. Nutr. Metab. 2017, 14, 14. [CrossRef] [PubMed]

14. Gowin, E.; Horst-Sikorska, W. Żelazne zapasy-Komu w XXI wieku grozi niedobór żelaza? (Iron stores-Who is at risk of iron deficiency in 21st century?). Farm. Wspótczesna 2010, 3, 139-146.

15. Swanson, C.A. Iron intake and regulation: Implications for iron deficiency and iron overload. Alcohol 2003, 30, 99-102. [CrossRef]

16. Gutowska, I.; Machoy, Z.; Machoy-Mokrzynska, A.; Machalinski, B. The role of iron in metal-metal interactions in hard tissues of roe deer (Capreolus Capreolus L.). Ann. Acad. Med. Stetin. 2009, 55, 16-21.

17. Muñoz, M.; García-Erce, J.A.; Remacha, Á.F. Disorders of iron metabolism. Part II: Iron deficiency and iron overload. J. Clin. Pathol. 2011, 64, 287-296. [CrossRef]

18. Bacon, B.R.; Adams, P.C.; Kowdley, K.V.; Powell, L.W.; Tavill, A.S. Diagnosis and management of hemochromatosis: 2011 Practice Guideline by the American Association for the Study of Liver Diseases. Hepatology 2011, 54, 328-343. [CrossRef]

19. Cho, N.H.; Shaw, J.E.; Karuranga, S.; Huang, Y.; da Rocha Fernandes, J.D.; Ohlrogge, A.W.; Malanda, B. IDF Diabetes Atlas: Global estimates of diabetes prevalence for 2017 and projections for 2045. Diabetes Res. Clin. Pract. 2018, 138, 271-281. [CrossRef]

20. Krisai, P.; Leib, S.; Aeschbacher, S.; Kofler, T.; Assadian, M.; Maseli, A.; Todd, J.; Estis, J.; Risch, M.; Risch, L.; et al. Relationships of iron metabolism with insulin resistance and glucose levels in young and healthy adults. Eur. J. Intern. Med. 2016, 32, 31-37. [CrossRef]

21. Hua, Y.; Clark, S.; Ren, J.; Sreejayan, N. Molecular mechanisms of chromium in alleviating insulin resistance. J. Nutr. Biochem. 2012, 23, 313-319. [CrossRef] [PubMed] 
22. Baltaci, N.G.; Guler, C.; Ceylan, H.; Kalin, S.N.; Adem, S.; Kocpinar, E.F.; Erdoğan, O.; Budak, H. In vitro and in vivo effects of iron on the expression and activity of glucose 6-phosphate dehydrogenase, 6-phosphogluconate dehydrogenase, and glutathione reductase in rat spleen. J. Biochem. Mol. Toxicol. 2019, 33, e22229. [CrossRef] [PubMed]

23. Sampaio, F.A.; Monte Feitosa, M.; Hermes Sales, C.; Costa e Silva, D.M.; Clímaco Cruz, K.J.; Oliveira, F.E.; Colli, C.; do Nascimento Marreiro, D. Influence of magnesium on biochemical parameters of iron and oxidative stress in patients with type 2 diabetes. Nutr. Hosp. 2014, 30, 570-576. [CrossRef]

24. Soliman, A.T.; De Sanctis, V.; Yassin, M.; Soliman, N. Iron deficiency anemia and glucose metabolism. Acta Biomed. 2017, 88, 112-118. [CrossRef]

25. Jiang, F.; Sun, Z.Z.; Tang, Y.T.; Xu, C.; Jiao, X.Y. Hepcidin expression and iron parameters change in type 2 diabetic patients. Diabetes Res. Clin. Pract. 2011, 93, 43-48. [CrossRef]

26. Jatobá, C.A.N.; De Rezende, A.A.; De Paiva Rodrigues, S.J.; De Almeida Câmara, M.M.; Das Graças Almeida, M.; Freire-Neto, F.; Da Rocha, L.R.M.; Da Medeiros, A.C.; Brandão-Neto, J.; De Carvalho Formiga, M.C.; et al. Liver iron overload induced by tamoxifen in diabetic and non-diabetic female wistar rats. BioMetals 2008, 21, 171-178. [CrossRef]

27. Cooksey, R.C.; Jones, D.; Gabrielsen, S.; Huang, J.; Simcox, J.; Luo, B.; Soesanto, Y.; Rienhoff, H.; Abel, E.D.; McClain, D. Dietary iron restriction or iron chelation protects from diabetes and loss of beta-cell function in the obese (Ob/Ob Lep-/-) mouse. Am. J. Physiol. Endocrinol. Metab. 2010, 298, 1236-1243. [CrossRef]

28. Khan, A.R.; Awan, F.R. Metals in the pathogenesis of type 2 diabetes. J. Diabetes Metab. Disord. 2014, 13, 16. [CrossRef]

29. Renuka, P.; Vasantha, M. Study of the serum levels of iron, ferritin and magnesium in diabetic complications. Int. J. Pharm. Clin. Res. 2016, 8, 254-259.

30. Vieyra-Reyes, P.; Millan-Aldaco, D.; Palomero-Rivero, M.; Jimenez-Garces, C.; Hernandez-Gonzalez, M. An iron-deficient diet during development induces oxidative stress in relation to age and gender in wistar rats. J. Physiol. Biochem. 2017, 73, 99-110. [CrossRef]

31. Ceccatelli, S.; Cottrill, B.; Dinovi, M.; Dogliotti, E.; Edler, L.; Knutsen, H.K.; Lundebye, A.; Metzler, M.; Nebbia, C.S.; Rietjens, I.; et al. Scientific opinion on the risks to public health related to the presence of chromium in food and drinking water. EFSA J. 2014, 12, 1-261. [CrossRef]

32. European Food Safety Authority. Scientific opinion on dietary reference values for chromium. EFSA J. 2014, 12, 3759. [CrossRef]

33. McIver, D.J.; Grizales, A.M.; Brownstein, J.S.; Goldfine, A.B. Risk of type 2 diabetes is lower in US adults taking chromium-containing supplements. J. Nutr. 2015, 145, 2675-2682. [CrossRef] [PubMed]

34. Clodfelder, B.J.; Chang, C.; Vincent, J.B. Absorption of the biomimetic chromium cation triaqua-M3-oxo$\mu$-hexapropionatotrichromium(III) in rats. Biol. Trace Elem. Res. 2004, 98, 159-169. [CrossRef]

35. Staniek, H.; Kostrzewska-Poczekaj, M.; Arndt, M.; Szyfter, K.; Krejpcio, Z. Genotoxicity assessment of chromium(III) propionate complex in the rat model using the comet assay. Food Chem. Toxicol. 2010, 48, 89-92. [CrossRef] [PubMed]

36. Staniek, H.; Krejpcio, Z.; Iwanik, K. Evaluation of the acute oral toxicity class of tricentric chromium(III) propionate complex in rat. Food Chem. Toxicol. 2010, 48, 859-864. [CrossRef]

37. Staniek, H.; Krejpcio, Z. The effects of supplementary Cr3 (chromium(III) propionate complex) on the mineral status in healthy female rats. Biol. Trace Elem. Res. 2017, 180, 90-99. [CrossRef]

38. Vincent, J.B.; Love, S. The binding and transport of alternative metals by transferrin. Biochim. Biophys. Acta 2012, 1820, 362-378. [CrossRef]

39. Earnshaw, A.; Figgis, B.; Lewis, J. Chemistry of polynuclear compounds. Part VI. Magnetic properties of trimeric chromium and iron carboxylates. J. Chem. Sociecty A Inorganic Phys. Theor. 1966, 1656-1663. [CrossRef]

40. Reeves, P.G. Symposium: Animal diets for nutritional and toxicologicalrresearch. Exp. Biol. 1997, 127, 838-841. [CrossRef]

41. Sacks, D.B.; Arnold, M.; Bakris, G.L.; Bruns, D.E.; Horvath, A.R.; Kirkman, M.S.; Lernmark, A.; Metzger, B.E.; Nathan, D.M. Guidelines and recommendations for laboratory analysis in the diagnosis and management of diabetes mellitus. Diabetes Care 2011, 34, e61-e99. [CrossRef] [PubMed]

42. Bairaktari, E.T.; Seferiadis, K.I.; Elisaf, M.S. Evaluation of methods for the measurement of low-density lipoprotein cholesterol. J. Cardiovasc. Pharmacol. Ther. 2005, 10, 45-54. [CrossRef] 
43. Shephard, M.D.S.; Whiting, M.J. Falsely low estimation of triglycerides in lipemic plasma by the enzymatic triglyceride method with modified trinder's chromogen. Clin. Chem. 1990, 36, 325-329. [CrossRef] [PubMed]

44. Thomas, L. Clinical Laboratory Diagnosis. Use and Assessment of Clinical Laboratory Results; TH Books Verlagsgesllschaft: Frankfurt, Germany, 1998.

45. Schumann, G.; Klauke, R. New IFCC reference procedures for the determination of catalytic activity concentrations of five enzymes in serum: Preliminary upper reference limits obtained in hospitalized subjects. Clin. Chim. Acta 2003, 327, 69-79. [CrossRef]

46. Burtis, C.A.; Ashwood, E.R. Tietz Textbook of Clinical Chemistry, 3rd ed.; Saunders: Philadelphia, PA, USA, 1999.

47. Horáková, D.; Štěpánek, L.; Janout, V.; Janoutová, J.; Pastucha, D.; Kollárová, H.; Petráková, A.; Štěpánek, L.; Husár, R.; Martiník, K. Optimal homeostasis model assessment of insulin resistance (HOMA-IR) cut-offs: A cross-sectional study in the Czech population. Medicina 2019, 55, 158. [CrossRef]

48. Pisprasert, V.; Ingram, K.H.; Lopez-Davila, M.F.; Munoz, A.J.; Garvey, W.T. Limitations in the use of indices using glucose and insulin levels to predict insulin sensitivity: Impact of race and gender and superiority of the indices derived from oral glucose tolerance test in African Americans. Diabetes Care 2013, 36, 845-853. [CrossRef]

49. Cacho, J.; Sevillano, J.; De Castro, J.; Herrera, E.; Ramos, M.P. Validation of simple indexes to assess insulin sensitivity during pregnancy in wistar and sprague-dawley rats. Am. J. Physiol. Endocrinol. Metab. 2008, 295, 1269-1276. [CrossRef]

50. Simcox, J.A.; McClain, D.A. Iron and diabetes risk. Cell Metab. 2013, 17, 329-341. [CrossRef]

51. Kubiak, T. Rola transferyny w przeciwdziałaniu stresowi oksydacyjnemu indukowanemu wolnym żelzaem w organizmie i jej potencjalne związki z rozwojem nowotworów. Kosmos. Probl. Nauk Biol. 2013, 62, 501-505.

52. Park, E.; Glei, M.; Knöbel, Y.; Pool-Zobel, B.L. Blood mononucleocytes are sensitive to the DNA damaging effects of iron overload-in vitro and ex vivo results with human and rat cells. Mutat. Res. Fundam. Mol. Mech. Mutagen. 2007, 619, 59-67. [CrossRef]

53. Chitturi, R.; Baddam, V.R.; Prasad, L.; Prashanth, L.; Kattapagari, K. A review on role of essential trace elements in health and disease. J. Dr. NTR Univ. Heal. Sci. 2015, 4, 75. [CrossRef]

54. Márquez-Ibarra, A.; Huerta, M.; Villalpando-Hernández, S.; Ríos-Silva, M.; Díz-Reval, M.I.; Cruzblanca, H.; Mancilla, E.; Trujillo, X. The effects of dietary iron and capsaicin on hemoglobin, blood glucose, insulin tolerance, cholesterol, and triglycerides, in healthy and diabetic wistar rats. PLoS ONE 2016, 11, e0152625. [CrossRef] [PubMed]

55. Cooksey, R.C.; Jouihan, H.A.; Ajioka, R.S.; Hazel, M.W.; Jones, D.L.; Kushner, J.P.; McClain, D.A. Oxidative stress, $\beta$-cell apoptosis, and decreased insulin secretory capacity in mouse models of hemochromatosis. Endocrinology 2004, 145, 5305-5312. [CrossRef] [PubMed]

56. Edgerton, D.S.; Kraft, G.; Smith, M.; Farmer, B.; Williams, P.E.; Coate, K.C.; Printz, R.L.; O’Brien, R.M.; Cherrington, A.D. Insulin's direct hepatic effect explains the inhibition of glucose production caused by insulin secretion. JCI Insight 2017, 2, e91863. [CrossRef] [PubMed]

57. Kulaksiz, H.; Fein, E.; Redecker, P.; Stremmel, W.; Adler, G.; Cetin, Y. Pancreatic $\beta$-cells express hepcidin, an iron-uptake regulatory peptide. J. Endocrinol. 2008, 197, 241-249. [CrossRef] [PubMed]

58. Sivasankari, J.; Thiruchelvan, V. Serum ferritin: An early marker of insulin resistance in metabolic syndrome. Int. J. Sci. Study 2017, 5, 59-64. [CrossRef]

59. Choi, J.S.; Koh, I.U.; Lee, H.J.; Kim, W.H.; Song, J. Effects of excess dietary iron and fat on glucose and lipid metabolism. J. Nutr. Biochem. 2013, 24, 1634-1644. [CrossRef]

60. Noetzli, L.J.; Mittelman, S.D.; Watanabe, R.M.; Coates, T.D.; Wood, J.C. Pancreatic iron and glucose dysregulation in thalassemia major. Am. J. Hematol. 2012, 87, 155-160. [CrossRef]

61. Staniek, H.; Wójciak, R.W. The combined effects of iron excess in the diet and chromium(III) supplementation on the iron and chromium status in female rats. Biol. Trace Elem. Res. 2018, 184, 398-408. [CrossRef]

62. Silva, M.; Silva, M.E.; de Paula, H.; Carneiro, C.M.; Pedrosa, M.L. Iron overload alters glucose homeostasis, causes liver steatosis, and increases serum triacylglycerols in rats. Nutr. Res. 2008, 28, 391-398. [CrossRef]

63. Prasad, A. Role of chromium compounds in diabetes. Indian J. Pharm. Pharmacol. 2016, 3, 17. [CrossRef]

64. Swaroop, A.; Bagchi, M.; Preuss, H.G.; Zafra-Stone, S.; Ahmad, T.; Bagchi, D. Benefits of Chromium(III) Complexes in Animal and Human Health, 2nd ed.; Elsevier: Amsterdam, The Netherlands, 2019. [CrossRef] 
65. Vincent, J.B. Effects of chromium supplementation on body composition, human and animal health, and insulin and glucose metabolism. Curr. Opin. Clin. Nutr. Metab. Care 2019, 22, 483-489. [CrossRef] [PubMed]

66. Sadri, H.; Larki, N.N.; Kolahian, S. Hypoglycemic and hypolipidemic effects of leucine, zinc, and chromium, alone and in combination, in rats with type 2 diabetes. Biol. Trace Elem. Res. 2017, 180, 246-254. [CrossRef] [PubMed]

67. Pala, R.; Sari, M.A.; Erten, F.; Er, B.; Tuzcu, M.; Orhan, C.; Deeh, P.B.D.; Sahin, N.; Cinar, V.; Komorowski, J.R.; et al. The effects of chromium picolinate on glucose and lipid metabolism in running rats. J. Trace Elem. Med. Biol. 2020, 58, 126434. [CrossRef] [PubMed]

68. Turgut, M.; Cinar, V.; Pala, R.; Tuzcu, M.; Orhan, C.; Telceken, H.; Sahin, N.; Deeh, P.B.D.; Komorowski, J.R.; Sahin, K. Biotin and chromium histidinate improve glucose metabolism and proteins expression Levels of IRS-1, PPAR- $\gamma$, and NF-KB in exercise-trained rats. J. Int. Soc. Sports Nutr. 2018, 15. [CrossRef]

69. Jovanović, L.; Pantelić, M.; Prodanović, R.; Vujanac, I.; Đurić, M.; Tepavčević, S.; Vranješ-Đurić, S.; Korićanac, G.; Kirovski, D. Effect of peroral administration of chromium on insulin signaling pathway in skeletal muscle tissue of holstein calves. Biol. Trace Elem. Res. 2017, 180, 223-232. [CrossRef]

70. Yang, X.; Palanichamy, K.; Ontko, A.C.; Rao, M.N.A.; Fang, C.X.; Ren, J.; Sreejayan, N. A newly synthetic chromium complex-Chromium(phenylalanine) 3 improves insulin responsiveness and reduces whole body glucose tolerance. FEBS Lett. 2005, 579, 1458-1464. [CrossRef]

71. Feng, W.; Li, Q.; Wang, W.; Chen, Y.; Zhang, W.; Zhao, T.; Mao, G.; Wu, X.; Yang, L. Influence of chronic Toxicity, Lipid Metabolism, Learning and Memory Ability, and Related Enzyme in Sprague-Dawley Rats by long-term chromium malate supplementation. Biol. Trace Elem. Res. 2019, 187, 243-257. [CrossRef]

72. Seif, A.A. Chromium picolinate inhibits cholesterol-induced stimulation of platelet aggregation in hypercholesterolemic rats. Ir. J. Med. Sci. 2015, 184, 291-296. [CrossRef]

73. Sahin, N.; Sahin, K.; Erkal, N. The effect of chromium added into basal diet on serum total protein, urea, triglyceride, cholesterol, and serum and tissue chromium, zinc, copper levels in rabbits. Turkish J. Vet. Anim. Sci. 1999, 23, 109-113.

74. Zhang, Q.; Sun, X.; Xiao, X.; Zheng, J.; Li, M.; Yu, M.; Ping, F.; Wang, Z.; Qi, C.; Wang, T.; et al. The effect of maternal chromium status on lipid metabolism in female elderly mice offspring and involved molecular mechanism. Biosci. Rep. 2017, 37. [CrossRef] [PubMed]

75. Staniek, H.; Krejpcio, Z.; Wieczorek, D. The effects of high dietary doses of chromium(III) complex with propionic acid on nutritional and selected blood indices in healthy female rats. Biol. Trace Elem. Res. 2016, 171, 192-200. [CrossRef] [PubMed]

76. Król, E.; Krejpcio, Z. Evaluation of anti-diabetic potential of chromium(III) propionate complex in high-fat diet fed and STZ injected rats. Food Chem. Toxicol. 2011, 49, 3217-3223. [CrossRef] [PubMed]

77. Doddigarla, Z.; Ahmad, J.; Parwez, I. Effect of chromium picolinate and melatonin either in single or in a combination in high carbohydrate diet-fed male wistar rats. BioFactors 2016, 42, 106-114. [CrossRef] [PubMed]

78. Guo, W.L.; Shi, F.F.; Li, L.; Xu, J.X.; Chen, M.; Wu, L.; Hong, J.L.; Qian, M.; Bai, W.D.; Liu, B.; et al. Preparation of a novel grifola frondosa polysaccharide-chromium (III) complex and its hypoglycemic and hypolipidemic activities in high fat diet and streptozotocin-induced diabetic mice. Int. J. Biol. Macromol. 2019, 131, 81-88. [CrossRef]

79. Tang, H.; Xiao, Q.; Xu, H.; Zhang, Y. Hypoglycemic activity and acute oral toxicity of chromium methionine complexes in mice. J. Trace Elem. Med. Biol. 2015, 29, 136-144. [CrossRef] [PubMed]

80. Li, F.; Wu, X.; Zou, Y.; Zhao, T.; Zhang, M.; Feng, W.; Yang, L. Comparing anti-hyperglycemic activity and acute oral toxicity of three different trivalent chromium complexes in mice. Food Chem. Toxicol. 2012, 50, 1623-1631. [CrossRef]

(C) 2020 by the authors. Licensee MDPI, Basel, Switzerland. This article is an open access article distributed under the terms and conditions of the Creative Commons Attribution (CC BY) license (http://creativecommons.org/licenses/by/4.0/). 